\title{
Potential of mycorrhizal inocula to improve growth, nutrition and enzymatic activities in Retama sphaerocarpa compared with chemical fertilization under drought conditions
}

\author{
E. Armada ${ }^{1}$, O. López-Castillo ${ }^{1}$, A. Roldán ${ }^{2}$ and R. Azcón ${ }^{1 *}$ \\ ${ }^{1}$ Departamento de Microbiología del Suelo y Sistemas Simbióticos, Estación Experimental del Zaidín, CSIC, \\ 18008 Granada, Spain. ${ }^{2}$ Department of Soil and Water Conservation, Centro de Edafología y Biología Aplica- \\ da del Segura, CSIC, Campus de Espinardo, 30100 Murcia, Spain. *Corresponding author: rosario.azcon@, \\ eez.csic.es
}

\begin{abstract}
The growth of Retama sphaerocarpa under drought conditions was similarly increased by arbuscular mycorrhizal (AM) colonization [native AM fungal consortium (M), allochthonous Rhizophagus intraradices (RI)] or $\mathrm{H}_{3} \mathrm{PO}_{4}$ application [25 ppm P (1P) or 50 ppm P (2P)]. However, the antioxidant ascorbate peroxidase (APX) activity was increased by P-fertilization and decreased by AM colonization in plants of similar size, which revealed possible AM protection against drought. RI was most effective in enhancing $\mathrm{P}$ and it also reduced glutathione reductase (GR) activity compared with plants of similar biomass from other treatments. In a subsequent study the mixture of autochthonous inocula (AM fungal consortium (M) plus native Bacillus thuringiensis (B)) were able to fortify $\mathrm{K}_{2} \mathrm{SO}_{4}$ fertilization [5 $\mathrm{mM} \mathrm{K}(1 \mathrm{~K})$ or $10 \mathrm{mM} \mathrm{K}(2 \mathrm{~K})$ ] on $R$. sphaerocarpa under drought. Dual inocula increased nutrient content only in plants fertilized with $1 \mathrm{~K}$, while $2 \mathrm{~K}$ even decreased the abundance of arbuscules. The reduced superoxide dismutase (SOD) and APX and the elimination of catalase (CAT) and GR activities found in coinoculated K-fertilized plants suggested the lowest oxidative stress and the highest potential to cope with drought irrespective of nutrition. In both experiments inocula enhanced soil enzymatic activities, which also contributed to higher performance of inoculated plants under drought.
\end{abstract}

Keywords: Drought stress, mycorrhizal-colonization, P or K fertilization, antioxidant activities, Retama sphaerocarpa nutrition, enzymatic soil activities

\section{Introduction}

Drought and water stress are considered the most important environmental factors limiting plant growth in the world (Panozzo and Eagles 1999). High temperatures and dry climate have a strong relationship with soil degradation and desertification. The restoration of degraded areas must be started by reclaiming the vegetation as shrubs species and most of the revegetation programs have been developed by 
using autochthonous plant species that are the most appropriate for reclaiming degraded soils.

Restoration of natural vegetation in arid drought zones is quite difficult due to water and nutrient limitation. Application of chemical fertilizers implies the appearance of insoluble mineral complexes, these insoluble forms precipitated cannot be absorbed by plants (Rengel and Marschner 2005). As a consequence, a minimum of the applied fertilizers are acquired by plants. Nevertheless, the establishment of plant cover in these disturbed sites can be facilitated by beneficial soil microorganisms such as arbuscular mycorrhizal (AM) fungi. The interest of using microbial inoculation to recover degraded dry lands has led to evaluation of inocula effectiveness to enhance plant establishment under drought conditions (Armada et al. 2014). This biotechnology has been proposed to be ecologically important for the plant development in degraded ecosystems (Jeffries and Barea 2012).

Mycorrhizal fungi colonize the roots of more than $90 \%$ of plant species having mutual plant and fungus benefit (Smith and Read 2008) and this symbiosis can improve the nutritional status and growth of plants under both optimal and restricted water levels. AM fungi represent an important biological factor for plants to thrive in water-limited conditions not only by increasing the supply of nutrients, but also by helping plants to support water stress (Medina and Azcón 2012). Selected microorganisms may contribute to plant establishment and growth particularly limited under semiarid conditions (Armada et al. 2014).

Drought may reduce AM fungus root colonization, but the inoculation of efficient fungi may help enhancing colonization and consequently population of AM fungi in this environment. The low microbiological activity of arid soils, due to the low density of microbial propagules, may be critical to the successful reestablishment and recovery of desertified ecosystems. Thus, native strains could be, presumably, the most effective in semiarid sites (Armada et al. 2014). Among different AM fungal species Rhizophagus intraradices have been reported an efficient endophyte in terms of soil water uptake (Marulanda et al. 2003) and in increasing plant growth and nutrition under drought conditions (Marulanda et al. 2006).

We hypothesised that under drought conditions autochthonous plants will be particularly benefited from inoculation with a whole native AM fungi consortium due to the diversity and functionality of autochthonous mycorrhizal community than from the inoculation with a single drought adapted mycorrhizal isolate as $R$. intraradices (from our collection). Presumably the inoculation with a complex fungal community would have a greater buffer capacity against the water stress than a single fungal inoculum (Caravaca et al. 2005).

A general trend in the beneficial effect of mycorrhization is associated with phosphorus acquisition in colonized plants and this is an important mechanism related to plant drought tolerance as has been reported by Augé (2004).

The inoculation with adapted symbiotic microorganism as autochthonous AM fungi has proved their effectiveness under water stress (Marulanda et al. 2006) and they been proposed with regards the improvement of the performance of plants in semi-arid and arid areas (Caravaca et al. 2005). However, information on the comparative role of autochthonous AM fungal consortium with fertilizers on plant stress tolerance is missing. Revegetation with the native woody legumes Retama sphaerocarpa in nutrient-deficient arid soils has proven to be more effective than with exotic plants under such unfertile and water limited conditions (Caravaca et al. 2005).

Drought stress can trigger an oxidative burst, induce an array of oxidant enzymes expression (Gururani et al. 2013) and as result, plants are able to counteract drought stress by modulating levels of some antioxidant enzymatic systems (Koussevitzky et al. 2008). 
Plants have this alternative defence strategy as a tool to overcome the stress constraints. There are few studies regarding the changes in the activity of antioxidant enzymes in plants modulated by the microbial inoculations under water stress conditions and results reported are highly variable (Armada et al. 2014; Ortiz et al. 2015).

To address the mycorrhizal drought tolerance strategies in $R$. sphaerocarpa we selected in a first experiment two types of drought adapted mycorrhizal inocula (autochthonous fungal mixture or the reference $R$. intraradices) and the effect of these biological treatments on drought tolerance were compared with two levels of phosphorus fertilization, 25 and $50 \mathrm{ppm} \mathrm{P}$ as $\mathrm{H}_{3} \mathrm{PO}_{4}$. Drought tolerance of $R$. sphaerocarpa was determined assessing growth, nutrient acquisition, mycorrhizal development and antioxidant enzymatic activities according to the chemical or biological treatments applied using a Mediterranean arid soil under drought conditions. A second experiment was also carried out using the same plant, soil and environmental conditions. This second experiment was planned based on the wellknown fact that potassium is the main element related with the alleviation of osmotic stress by being involved in photosynthetic $\mathrm{CO}_{2}$ fixation and the protection of chloroplasts from photooxidative damage (Romheld and Kirkby 2010). $\mathrm{K}^{+}$as inorganic osmolyte is important in water homeostasis under drought and able to regulate osmotic balance, turgor pressure, stomatal opening and transpiration (Loutfy et al. 2012). The objective of this second study was to assess to what extent the effect of the single potassium fertilizer [two levels, 5 or $10 \mathrm{mM} \mathrm{K}(1 \mathrm{~K}$ or $2 \mathrm{~K})$ as $\mathrm{K}_{2} \mathrm{SO}_{4}$ ], may be improved by the addition of autochthonous inocula [Bacillus thuringiensis (B) plus the mycorrhizal consortium (M)]. Both inocula were isolated from the same rhizosphere samples as $B$. thuringiensis, which had been selected for exerting a significant effect on drought tolerance in native plants such as Lavandula,
Trifolium, Salvia and others (Armada et al. 2014). Moreover, in a recent study with a plant of agronomic interest as maize the coordinated effect of these autochthonous two microbial groups (B. thuringiensis + AM fungi) under drought conditions was evidenced. $B$. thuringiensis increased mainly maize nutrition and AM fungi were more active improving stress tolerance/homeostatic mechanisms (as plant aquaporins and physiological functions) (Armada et al. 2015). Thus, we here hypothesised that these combined biological treatments (MB) could interact with chemical fertilizers $(1 \mathrm{~K}$ or $2 \mathrm{~K})$ influencing growth, nutrition, mycorrhizal development and drought tolerance in those drought-adapted Mediterranean plants growing under drought conditions.

Soil enzyme activities are an alternative way of monitoring the soil alterations and perturbations (Naseby and Lynch 1997). In arid and degraded soils the microbial populations and their activities are low mainly due to the lack of water and suitable substrates (Medina and Azcón 2012). Thus, soil enzymatic activities play an important role in the mineralization of the organic products and were assessed as index of microbial soil activity.

The efficacy of native strains from different sites lead to different effects on plant growth and nutrients uptake (Ortiz et al. 2015). The aims of this study is to ascertain the comparative effect of mycorrhizal inocula (autochthonous or allochthonous) and P fertilizers (two levels), and to verify the relevance of the AM strain origin or P-fertilizer to the ability to enhance plant growth, nutrition, biochemical antioxidant values related to drought tolerance under semiarid conditions. In addition, to test the impact of dual microbial inoculations (autochthonous AM fungi and the bacteria $B$. thuringiensis) and/or the application of fertilizer potassium (two levels) on $R$. sphaerocarpa growth, nutrition and plant antioxidant activities. In both experiments 
changes in soil enzymatic activities were measured.

\section{Materials and Methods}

\subsection{Experimental design}

Two independent greenhouse pot experiments were carried out in this study. In Experiment I, we determined the effectiveness of a consortium of autochthonous mycorrhizal fungi $(\mathrm{M})$ or $R$. intraradices $(\mathrm{RI})$ compared with two phosphorus levels [25 ppm P (1P) or $50 \mathrm{ppm} \mathrm{P}(2 \mathrm{P})$ as $\mathrm{H}_{3} \mathrm{PO}_{4}$ ] over non-inoculated unfertilized control to increase plant growth, nutrition mycorrhizal development and biochemical activities under drought conditions.

In Experiment II, we examined how two levels of $\mathrm{K}$ in the growing medium $[5 \mathrm{mM} \mathrm{K}(1 \mathrm{~K})$ and $10 \mathrm{mM} \mathrm{K}$ $(2 \mathrm{~K})$ as $\mathrm{K}_{2} \mathrm{SO}_{4}$ ], applied as single fertilizer or when these two K levels were dually inoculated with autochthonous microorganism as AM fungi (consortium) plus $B$. thuringiensis affected plant drought tolerance in terms of plant growth, nutrition, mycorrhizal development and biochemical parameters under drought conditions.

In both experiments soil enzymatic activities, as soil quality biomarkers, were determined. Five replicates of each treatments were included resulting a total of 25 pots in experiment I and 20 pots in experiment II.

\subsection{Soil characteristics}

The experimental soil used was selected from an area located in the Natural Ecological Park "Vicente Blanes" in Molina de Segura, province of Murcia (southeastern Spain) (coordinates 38 $12^{\prime} \mathrm{N}, 1^{\circ} 13^{\prime}$ $\mathrm{W}, 393 \mathrm{~m}$ altitude). The climate is semiarid Mediterranean, with an average annual rainfall lower than $270 \mathrm{~mm}$ and the potential evapotranspiration (ETP) reaches approximately $1000 \mathrm{~mm}$. The mean annual temperature is $19.2^{\circ} \mathrm{C}$ with absence of frost period. The soil in is a Typic Torriorthent (SSS 2006) very little developed with a low organic matter content and a silty clay texture that facilitates the degradation of soil structure. The vegetation in the zone was dominated by Piptatherum miliaceum L. Cosson., Trifolium repens L., some shrubs of Thymus vulgaris L., Rosmarinus officinalis L. and $R$. sphaerocarpa growing with patchy distribution.

The main soil characteristics were $\mathrm{pH} 8.90$, P-Olsen $1.36 \mathrm{mg} \mathrm{kg}^{-1}$, organic carbon $0.94 \%$, total $\mathrm{N} 0.22 \%$, and an electric conductivity of $1.55 \mathrm{dS} \mathrm{m}^{-1}$. Both microcosm experiments were conducted in this soil.

\subsection{Isolation, production and identification of drought-tolerant microorganism}

The microbial inocula used in these experiments were isolated from the rhizosphere of plants naturally growing in this semiarid soil described above. This rhizosphere soil containing colonized roots, spores and mycelia belonging to the native adapted AM fungi was cultivated for inoculum production (Marulanda et al. 2006).

For inocula production the rhizosphere soil was bulked in an open pot culture of Zea mays and Trifolium repens with sterile soil/sand $(1: 1 \mathrm{v} / \mathrm{v})$ mixture. After six months of plant growth the shoots were eliminated and the under-grown part (mycorrhizal roots plus soil possessing fungal spores and mycelium) was maintained by storage for three to six months in polyethylene bags at $4{ }^{\circ} \mathrm{C}$ and used as a stock culture. The mycorrhizal fungus $R$. intraradices (EEZ 195) from our collection (Estación Experimental del Zaidín) was also used in the Experiment I as reference.

Plants were inoculated with $R$. intraradices or a consortium of indigenous AM fungi. The fungal spores were isolated by wet-sieving and decanting as de- 
scribed by Ruíz-Lozano and Azcón (1995) and all the spores obtained were morphologically similar to Septoglomus constrictum (EEZ 198), Diversispora aunantia (EEZ 199), Archaeospora trappei (EEZ 200), Glomus versiforme (EEZ 201) and Paraglomus ocultum (EEZ 202) compared to those from our current EEZ collection. We used as autochthonous mycorrhizal (M) inoculum a mixture of each one of these fungal species.

From the corresponding stock culture, $5 \mathrm{~g}$ of this fungal AM consortium (M) or R. intraradices (RI) from collection was applied as inocula to the corresponding pots, having both inocula similar an average of 80 spores/g of soil and roots with $75 \%$ of AM colonization. The $\mathrm{M}$ inoculum or the reference $R$. intraradices were applied to each one of the appropriate pots at transplanting time just below the seedlings. Nonmycorrhizal treatments received the same amount of autoclaved inoculum together with a $2 \mathrm{~mL}$ aliquot of natural soil filtrate $(<20 \mathrm{~mm})$ containing soil microorganisms with the exception of AM fungi.

In Experiment II an autochthonous bacteria was also used in interaction with autochthonous AM fungi. The bacterium was isolated from the above-mentioned soil (a mixture of rhizospheres from several autochthonous plants species). A homogenate of $1 \mathrm{~g}$ soil in $9 \mathrm{~mL}$ sterile water was diluted $\left(10^{-2}\right.$ to $\left.10^{-4}\right)$, plated on three different media [Yeast Manitol Agar, Potato Dextrose Agar or Luria-Bertani (LB) Agar] and then incubated at $28^{\circ} \mathrm{C}$ for $48 \mathrm{~h}$, to isolate bacteria from different taxonomic groups.

Identification of isolated autochthonous bacteria was done by sequencing the 16S rDNA gene. Bacterial cells were collected, diluted, lysed and their DNA used as a template in the PCR reactions. All reactions were conducted in $25 \mu \mathrm{L}$ volume containing PCR buffer $10 \mathrm{X}, 50 \mathrm{mM} \mathrm{MgCl}_{2}, 10 \mu \mathrm{M}$ each primers 27F (AGAGTTTGATCCTGGCTCAG) and 1492R (GGTTACCTTGTTACGACTT), $5 \mathrm{U} / \mu \mathrm{L}$ of
Taq polymerase (Platinum, Invitrogen). The PCR was performed in a thermal cycle with the following conditions: $5 \mathrm{~min}$ at $95^{\circ} \mathrm{C}$, followed by 30 cycles of $45 \mathrm{~s}$ at $95^{\circ} \mathrm{C}, 45 \mathrm{~s}$ at $44{ }^{\circ} \mathrm{C}$ and $2 \mathrm{~min}$ at $72^{\circ} \mathrm{C}$, and finally one cycle of $10 \mathrm{~min}$ at $72{ }^{\circ} \mathrm{C}$. The products PCR of were analysed by $1 \%$ agarose gel electrophoresis and DNA was extracted and purified with the QIAquick Gel extraction kit (QUIAGEN) for subsequent sequencing in an automated DNA sequencer (PerKin-Elmer ABI Prism 373). Sequence data were compared to gene libraries (NCBI) using BLAST program, unambiguously identified the bacterium as Bacillus thuringiensis (Acession NR 043403.1, similarity 98\%). The bacteria were grown in $250-\mathrm{mL}$ flasks containing $50 \mathrm{~mL}$ of $\mathrm{LB}$ medium for $48 \mathrm{~h}$ at $28^{\circ} \mathrm{C}$. In the corresponding pots, plants were inoculated with $1 \mathrm{~mL}$ of the bacterial culture $\left(10^{8} \mathrm{cfu} \mathrm{mL}^{-1}\right)$ in the planting hole at sowing time. The bacterial inoculum was applied again 15 days later. In control treatments, $1 \mathrm{~mL}$ of sterilized bacterial culture was added.

Prior use soil was sieved (mesh diameter $=2 \mathrm{~mm}$ ) and sterilized by steam $\left(100{ }^{\circ} \mathrm{C}\right.$ for $1 \mathrm{~h}$ on 3 consecutive days). One month old seedlings of $R$. sphaerocarpa plants were transplanted to pots containing $0.750 \mathrm{~kg}$ of a 1:1 mixture of soil: sand $(\mathrm{v} / \mathrm{v})$ in Experiment I and 1:2 soil: sand mixture (v/v) in Experiment II. At transplanting time plants were inoculated with the appropriate inoculum.

\subsection{Plant growth conditions}

Plants (one per pot) were grown for seven and half months in a greenhouse under a day/night cycle of $16 / 8 \mathrm{~h}, 21 / 15{ }^{\circ} \mathrm{C}$ and $50 \%$ relative humidity. The photosynthetic photon flux density (PPFD) was $503 \mu \mathrm{mol} \mathrm{m} \mathrm{m}^{-2} \mathrm{~s}^{-1}$, as measured with a light-meter (LICOR, model LI-188B). Water loss was compensated by watering every day to reach $50 \%$ of waterholding capacity (WHC). During the first 2 weeks 
of plant growth constant soil water content close to water holding capacity was maintained. After this time, plants were allowed to dry until soil water content was $50 \%$ of water holding capacity and maintained under these conditions for additional 30 weeks. To achieve that, the soil moisture in the pots was measured each $24 \mathrm{~h}$ and the water was added to reach a maximum of $50 \%$ of water holding capacity. However, during the 24 -h period between each rewatering the soil water content was progressively decreased to a minimum value of $40 \%$ of water holding capacity. Soil moisture was measured with an ML2 X ThetaProbe (AT Delta$\mathrm{T}$ Devices Ltd, Cambridge, UK), which measures volumetric soil moisture content by responding to changes in the apparent dielectric constant of moist soil (White et al. 1994). This volumetric soil moisture is considered to be a normal environmental condition in dry Mediterranean areas. During the experimental time, a Hewitt's nutritive solution was applied weekly $\left(10 \mathrm{~mL} \mathrm{pot}^{-1}\right)$ modified to have $1 / 2 \mathrm{~N}$ and $1 / 4 \mathrm{P}$ concentrations. In Experiment I, the two $\mathrm{P}$ fertilization treatments were applied twice a week $(10 \mathrm{~mL})$ of $\mathrm{H}_{3} \mathrm{PO}_{4}$ solution along the four weeks after transplanting to reach the desired $\mathrm{P}$ concentrations ( 25 or $50 \mathrm{ppm} \mathrm{P}$ ) in the appropriate pots. Similarly, in Experiment II the two K fertilization treatments were applied twice a week (10 $\mathrm{mL}$ ) of $\mathrm{K}_{2} \mathrm{SO}_{4}$ solution along the four weeks after transplanting to reach the desired $\mathrm{K}$ concentrations $(5 \mathrm{mM}$ or $10 \mathrm{mM} \mathrm{K})$ in the corresponding pots.

\subsection{Parameters measured}

\subsubsection{Biomass production}

At harvest, seven and half months after transplanting in both Experiments, the root system was separated from the shoot and dry weights were measured after drying at $75^{\circ} \mathrm{C}$ for 2 days.

\subsubsection{Nutrient content}

Shoot content (mg per plant) of $\mathrm{P}, \mathrm{K}, \mathrm{Ca}$ and $\mathrm{Mg}$ as well as of Fe, Mn, $\mathrm{Zn}$ and $\mathrm{Cu}$ ( $\mu \mathrm{g}$ per plant) were determined by inductively coupled plasma optical emission spectrometry (ICP-OES). Mineral analyses were carried out by the Instrumentation Service (EEZCSIC), Granada, Spain.

\subsubsection{Mycorrhizal development}

Fungal colonization was assessed after clearing washed roots in $10 \% \mathrm{KOH}$ and staining with $0.05 \%$ trypan blue in lactic acid (v/v), according to Philips and Hayman (1970). The extent of mycorrhizal colonization was calculated according to the gridline intersect method Giovanneti and Mosse (1980) after counting 150 intersections. Mycorrhizal development was evaluated by the method of Trouvelot et al. (1986) using MYCOCALC software (http://www.dijon.inra.fr/mychintec/Mycocalc-prg/download.html). The parameters measured according to this method were the frequency of AM colonization in the sample $(\% \mathrm{~F})$, intensity of AM colonization $(\% \mathrm{~m})$ in the whole root system $(\% \mathrm{M})$, and relative and absolute arbusculum richness $(\%$ a and $\% \mathrm{~A})$ referred to the calculated whole root system respectively.

\subsubsection{Antioxidant enzymatic activities}

Shoot tissues were homogenized (Aroca et al. 2003) in a cold mortar with $4 \mathrm{~mL} 100 \mathrm{mM}$ phosphate buffer (pH 7.2) containing $60 \mathrm{mM} \mathrm{KH}_{2} \mathrm{PO}_{4}, 40 \mathrm{mM} \mathrm{K}_{2} \mathrm{HPO}_{4}$, $0.1 \mathrm{mM}$ diethylenetriaminepenta acetic acid (DTPA) and $1 \%(\mathrm{w} / \mathrm{v})$ polyvinylpolypyrrolidone (PVPP). The 
homogenate was centrifuged at $18,000 \mathrm{~g}$ for $10 \mathrm{~min}$ at $4{ }^{\circ} \mathrm{C}$, and the supernatant was used for enzyme activity determination. Total superoxide dismutase (SOD) activity (EC 1.15.1.1) (Burd et al. 2000) was measured on the basis of SOD's ability to inhibit the reduction of nitroblue tetrazolium (NBT) by superoxide radicals generated photochemically. One unit of SOD was defined as the amount of enzyme required to inhibit the reduction rate of NBT by $50 \%$ at $25^{\circ} \mathrm{C}$. Catalase (CAT) activity (EC 1.11.1.6) was measured as described by Aebi (1984) conducted in $2 \mathrm{~mL}$ reaction volume containing $50 \mathrm{mM}$ potassium phosphate buffer ( $\mathrm{pH} 7.0$ ), $10 \mathrm{mM} \mathrm{H}_{2} \mathrm{O}_{2}$ and $50 \mu \mathrm{L}$ of enzyme extract. Consumption of $\mathrm{H}_{2} \mathrm{O}_{2}$ (extinction coefficient $\left(\varepsilon_{240}\right)$ of $\left.39.6 \mathrm{mM}^{-1} \mathrm{~cm}^{-1}\right)$ at $240 \mathrm{~nm}$ for 1 min was monitored. Ascorbate peroxidase (APX) activity (EC 1.11.1.11) was measured in a $1 \mathrm{~mL}$ reaction volume containing $80 \mathrm{mM}$ potassium phosphate buffer $(\mathrm{pH}$ 7.0), $2.5 \mathrm{mM}$ hydrogen peroxide and $0.5 \mathrm{mM}$ sodium ascorbate. The $\mathrm{H}_{2} \mathrm{O}_{2}$ was added to start the reaction, and the decrease in absorbance at $290 \mathrm{~nm}$ was recorded for $1 \mathrm{~min}$ to determine the oxidation rate for ascorbate (Amako et al. 1994). Glutathione reductase (GR) activity (EC 1.20.4.2.) was estimated by measuring the decrease of absorbance at $340 \mathrm{~nm}$ due to the oxidation of NADPH (Carlberg and Mannervik 1985). The reaction mixture $(1 \mathrm{~mL})$ contained $50 \mathrm{mM}$ Tris buffer $3 \mathrm{mM} \mathrm{MgCl}_{2}$ (pH 7.5), $1 \mathrm{mM}$ oxidized glutathione, $50 \mu \mathrm{L}$ enzyme extract, and $0.3 \mathrm{mM} \mathrm{NADPH}$ was added and mixed thoroughly to begin the reaction. The results were expressed in mmol NADPH oxidized $\mathrm{mg}^{-1}$ protein, and the activity was calculated from the initial speed of reaction and the molar extinction coefficient of NADPH $\left(\mathrm{e}_{340}=6.22 \mathrm{mM}^{-1} \mathrm{~cm}^{-1}\right)$. Total soluble protein amount was determined using the Bradford (Bradford 1976) method and bovine serum albumin (BSA) as standard.

\subsubsection{Soil enzymatic activities}

In rhizosphere soil samples enzymatic activities were determined in both experiments.

Dehydrogenase activity was determined following Skujins' method (Skujins 1976), as modified by García et al. (1997). For this, $1 \mathrm{~g}$ of soil at $60 \%$ of its field capacity was exposed to $0.2 \mathrm{~mL}$ of $0.4 \%$ INT (2-p-iodophenyl-3- $p$-nitrophenyl-5-phenyltetrazolium chloride) in distilled water for $20 \mathrm{~h}$, at $22{ }^{\circ} \mathrm{C}$ in darkness. The INTF (iodo-nitrotetrazolium formazan) formed was extracted with $10 \mathrm{~mL}$ of methanol, by shaking vigorously for $1 \mathrm{~min}$ and filtering through a Whatman $\mathrm{N}^{\circ} 5$ filter paper. INTF was measured spectrophotometrically at $490 \mathrm{~nm}$.

Alkaline phosphatase activity was determined using p-nitrophenyl phosphate disodium (PNPP) $0.115 \mathrm{M}$ as substrate. Two milliliters of $0.5 \mathrm{M}$ sodium acetate buffer adjusted to $\mathrm{pH} 5.5$ using acetic acid (Naseby and Lynch 1997) and $0.5 \mathrm{~mL}$ of substrate were added to $0.5 \mathrm{~g}$ of soil and incubated at $37{ }^{\circ} \mathrm{C}$ for $90 \mathrm{~min}$. The reaction was stopped by cooling at $2{ }^{\circ} \mathrm{C}$ for 15 $\min$. Then, $0.5 \mathrm{~mL}$ of $0.5 \mathrm{M} \mathrm{CaCl}_{2}$ and $2 \mathrm{~mL}$ of $0.5 \mathrm{M}$ $\mathrm{NaOH}$ were added, and the mixture was centrifuged at $4000 \mathrm{rpm}$ for $5 \mathrm{~min}$. The $p$-nitrophenol (PNP) formed was determined in a spectrophotometer at $398 \mathrm{~nm}$ (Tabatabai and Bremner 1969). In controls, the substrate was added before the $\mathrm{CaCl}_{2}$ and $\mathrm{NaOH}$ addition. $\beta$-glucosidase was determined using $p$-nitrophenyl- $\beta$ D-glucopyranoside (PNG), $0.05 \mathrm{M}$ (Masciandaro et al. 1994) as substrate. This assay is also based on the release and detection of PNP. Two milliliters of 0.1 $\mathrm{M}$ maleate buffer ( $\mathrm{pH}$ 6.5) and $0.5 \mathrm{~mL}$ of substrate were added to $0.5 \mathrm{~g}$ of sample and incubated at 37 ${ }^{\circ} \mathrm{C}$ for $90 \mathrm{~min}$. The reaction was stopped with trishydroxymethyl aminomethane (THAM) according to Tabatabai (1982). The amount of PNP was determined in a spectrophotometer at $398 \mathrm{~nm}$ (Tabatabai and Bremner 1969). 
Urease activity was determined by the method of Nannipieri et al. (1980), and expressed as $\mu \mathrm{mol}$ $\mathrm{N}-\mathrm{NH}_{3} \mathrm{~g}^{-1}$ soil $\cdot \mathrm{h}^{-1}$.

\subsection{Statistical analyses}

Data from both experiments were analyzed using the SPSS 21 software package for Windows, employing one-way general linear model ANOVA (analysis of variance) to determine the effect of two mycorrhizal inocula compared with two levels of phosphorus fertilizer [25 ppm P (1P) or 50 ppm P (2P) as $\left.\mathrm{H}_{3} \mathrm{PO}_{4}\right]$ ) (Experiment I), and to evaluate the effect of dual microbial inoculations (autochthonous AM fungi and the bacteria $B$. thuringiensis) and /or the application of potassium fertilizer (two levels $[5 \mathrm{mM} \mathrm{K}(1 \mathrm{~K})$ and 10 $\mathrm{mM} \mathrm{K}(2 \mathrm{~K})$ as $\mathrm{K}_{2} \mathrm{SO}_{4}$ ] (Experiment II). The Duncan's multiple-range test (Duncan 1955) was used for post hoc analysis to determine differences between means. Differences were considered significant at $p \leq 0.05$. Percentage values were arc-sine-transformed before statistical analysis.

\section{Results}

\subsection{Experiment I}

Regarding the results of this experiment, all mycorrhiza inocula applied behaved similarly to $\mathrm{P}$ fertilization $(1 \mathrm{P}$ or $2 \mathrm{P})$ in terms of shoot dry mass production. The four treatments applied, similarly enhanced shoot dry biomass compared to control plants, but root development was lower in RI colonized plants (Table 1). In spite of non-significant differences in growth of $\mathrm{P}$ treated or mycorrhizal inoculated plants the highest shoot biomass ( $79 \%$ over control) was obtained in plants colonized by the consortium of autochthonous fungi (Table 1).

Shoot and root development of P-fertilized plants as well as some of the analyzed nutrients $(\mathrm{P}, \mathrm{K}, \mathrm{Ca}, \mathrm{Fe}$, $\mathrm{Mn}, \mathrm{Zn}$ and $\mathrm{Cu}$ ) reached similar values irrespective of $\mathrm{P}$ level applied (Table 1). Thus, the application of 25 ppm P (1P), under these drought environmental conditions, may be considered as the optimum amount of P-fertilization to reach the maximum plant growth and nutrition.

Regarding $\mathrm{P}$ and $\mathrm{K}$ content no-differences were observed in $\mathrm{P}$ fertilized plants, irrespective of $\mathrm{P}$ level and $\mathrm{M}$ inoculated having similar root development (Table 1). Nevertheless, the uptake of P, K, Ca or Mg was significantly higher in $R$. intraradices-colonized plants than in control plants having similar root biomass (Table 1).

The root development in $R$. intraradices colonized plants was more reduced than in the rest of treated plants (Table 1). As a result of lower root growth, lesser nutrients transport to the above grown parts is expected. However, the opposite effect was observed in $R$. intraradices inoculated plants since the uptake of macronutrients was higher in these plants. Results show that this fungus plays a significant role in the extra acquisition of some nutrients ( $\mathrm{P}, \mathrm{K}, \mathrm{Ca}$ and $\mathrm{Mg}$ ) under drought conditions (Table 1).

Moreover, in the case of $\mathrm{P}, R$. intraradices-colonized plants acquired the highest proportion of this nutrient, even more than plants P-fertilized with $50 \mathrm{ppm} P$ (Table 1). Regarding plant content of $\mathrm{K}, \mathrm{Ca}$ and $\mathrm{Mg}$ both mycorrhizal inocula (M or RI) resulted as active as the highest P-fertilization in the uptake of these nutrients (Table 1). 
Table 1. Comparative effect of fertilizers [1P (25 ppm P); 2P (50 ppm P)], authochthonous AM fungal consortium $(\mathrm{M})$ or the reference $R$. intraradices (RI), over control (C) on the dry weight of shoot and root ( $\mathrm{g}$ ) and content of $\mathrm{P}, \mathrm{K}, \mathrm{Ca}, \mathrm{Mg}$ (mg per plant), $\mathrm{Fe}, \mathrm{Mn}, \mathrm{Zn}$ and $\mathrm{Cu}$ ( $\mu \mathrm{g}$ per plant) of $R$. sphaerocarpa under drought conditions.

\begin{tabular}{|c|c|c|c|c|c|c|c|c|c|c|}
\hline & $\begin{array}{c}\text { Shoot } \\
\text { dry } \\
\text { weight }\end{array}$ & $\begin{array}{c}\text { Root } \\
\text { dry } \\
\text { weight }\end{array}$ & $P$ & K & $\mathrm{Ca}$ & $\mathrm{Mg}$ & $\mathrm{Fe}$ & $\mathrm{Mn}$ & $\mathrm{Zn}$ & $\mathrm{Cu}$ \\
\hline $\mathrm{C}$ & $1.37 \mathrm{a}$ & $1.71 \mathrm{a}$ & $1.3 \mathrm{a}$ & $7.7 \mathrm{a}$ & $10.6 \mathrm{a}$ & $2.1 \mathrm{a}$ & $158.6 \mathrm{~b}$ & $156.0 \mathrm{~b}$ & $140.6 \mathrm{~b}$ & $8.6 \mathrm{~b}$ \\
\hline $1 \mathrm{P}$ & $2.28 \mathrm{~b}$ & $2.81 \mathrm{~b}$ & $2.2 \mathrm{~b}$ & $16.2 \mathrm{~b}$ & $8.9 \mathrm{a}$ & $3.0 \mathrm{a}$ & $152.7 \mathrm{~b}$ & $142.9 \mathrm{~b}$ & $160.2 \mathrm{~b}$ & $8.1 \mathrm{~b}$ \\
\hline $2 \mathrm{P}$ & $2.02 \mathrm{~b}$ & $2.78 \mathrm{~b}$ & $2.2 \mathrm{~b}$ & $14.5 \mathrm{~b}$ & $15.7 \mathrm{ab}$ & $4.1 \mathrm{~b}$ & $136.9 \mathrm{ab}$ & $138.1 \mathrm{~b}$ & $151.6 \mathrm{~b}$ & $7.4 \mathrm{~b}$ \\
\hline M & $2.45 \mathrm{~b}$ & $2.70 \mathrm{ab}$ & $2.9 \mathrm{~b}$ & $15.1 \mathrm{~b}$ & $17.2 \mathrm{~b}$ & $6.5 \mathrm{~b}$ & $144.3 \mathrm{~b}$ & $143.4 \mathrm{~b}$ & $128.7 \mathrm{~b}$ & $8.7 \mathrm{~b}$ \\
\hline RI & $2.05 \mathrm{~b}$ & $1.57 \mathrm{a}$ & $4.8 \mathrm{c}$ & $17.7 \mathrm{~b}$ & $17.2 \mathrm{~b}$ & $5.3 \mathrm{~b}$ & $91.4 \mathrm{a}$ & $72.2 \mathrm{a}$ & $41.6 \mathrm{a}$ & $4.3 \mathrm{a}$ \\
\hline
\end{tabular}

Within each parameter values having a common letter are not significantly different $(p \leq 0.05)$ as determined by Duncan's multiple-range test $(\mathrm{n}=5)$.

The content of the micronutrients $\mathrm{Fe}, \mathrm{Mn}, \mathrm{Zn}$ and $\mathrm{Cu}$ did not significantly change irrespective of the applied treatments with the exception of $R$. intraradices that highly depressed the content of whatever micronutrient here analyzed (Table 1).
There were no-significant differences in the percentage of mycorrhizal root length produced by both mycorrhiza inocula. The intraradical mycorrhizal development was analyzed in terms of frequency $(\% \mathrm{~F})$, intensity $(\% \mathrm{M}$ and $\% \mathrm{~m})$ and relative and absolute arbusculum richness $(\% \mathrm{a}$ and $\% \mathrm{~A})$ in colonized roots (Table 2$)$.

Table 2. Mycorrhizal symbiotic development by the authochthonous AM fungal consortium (M) or the reference $R$. intraradices $(\mathrm{RI})$ on colonization frequency $(\% \mathrm{~F})$, intensity $(\% \mathrm{M})$, intensity of colonization $(\% \mathrm{~m})$, arbuscule abundance (\%a) and richness of arbuscules (\%A).

\begin{tabular}{llllll}
\hline & $\% \mathrm{~F}$ & $\% \mathrm{M}$ & $\% \mathrm{~m}$ & $\% \mathrm{a}$ & $\% \mathrm{~A}$ \\
\hline $\mathrm{M}$ & $100 \mathrm{a}$ & $28.9 \mathrm{a}$ & $28.9 \mathrm{a}$ & $56.6 \mathrm{a}$ & $20.6 \mathrm{a}$ \\
$\mathrm{RI}$ & $100 \mathrm{a}$ & $30.4 \mathrm{a}$ & $30.4 \mathrm{a}$ & $64.9 \mathrm{a}$ & $21.1 \mathrm{a}$ \\
\hline
\end{tabular}

Within each parameter values having a common letter are not significantly different $(p \leq 0.05)$ as determined by Duncan's multiple-range test $(\mathrm{n}=5)$. 
No nodule production was observed in spite of the application of an extract from non-sterilized natural soil presumably having Rhizobium.

Antioxidant activities were here analyzed as an index of the ability of plants to counteract the oxidative damage caused by the drought imposed. Results show that the APX activity was the highest in P-fertilized plants and the lowest in mycorrhizal inoculated plants of similar size (Table 1, Figure 1). For SOD and CAT activities the lowest values were observed in M- colonized plants that decreased both these activities compared to whatever level of $\mathrm{P}$ fertilization, while $R$. intraradices reduced GR activity (Figure 1).

The $\beta$-glucosidase activity increased by $176 \%$ in response to $\mathrm{M}$ inoculum application (Figure 2) and dehydrogenase activity was enhanced by both inocula but only $10 \%$. Non-significant differences on these enzymatic activities as result of the $\mathrm{P}$ fertilization were observed. Treatments applied did not change phosphatase and urease activities (Figure 2).
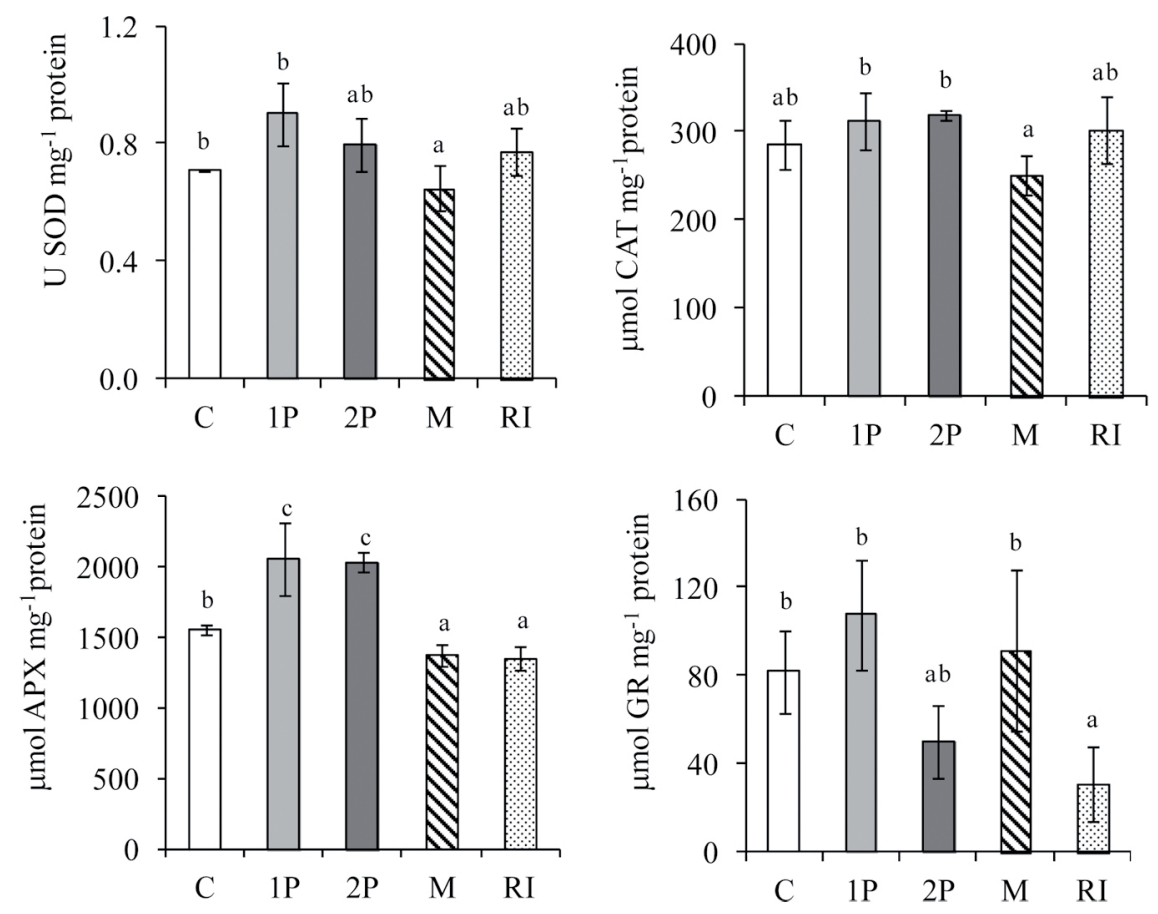

Figure 1. Comparative effect of fertilizers [1P (25 ppm P); 2P (50 ppm P)], authochthonous AM fungal consortium (M) or the reference $R$. intraradices (RI), over control (C) on superoxide dismutase (SOD), catalase (CAT), ascorbate peroxidase (APX) and glutathione reductase (GR) antioxidant activities in shoot of $R$. sphaerocarpa under drought conditions. Within each value bars having a common letter are not significantly different $(p \leq 0.05)$ as determined by Duncan's multiple-range test $(n=3)$. 

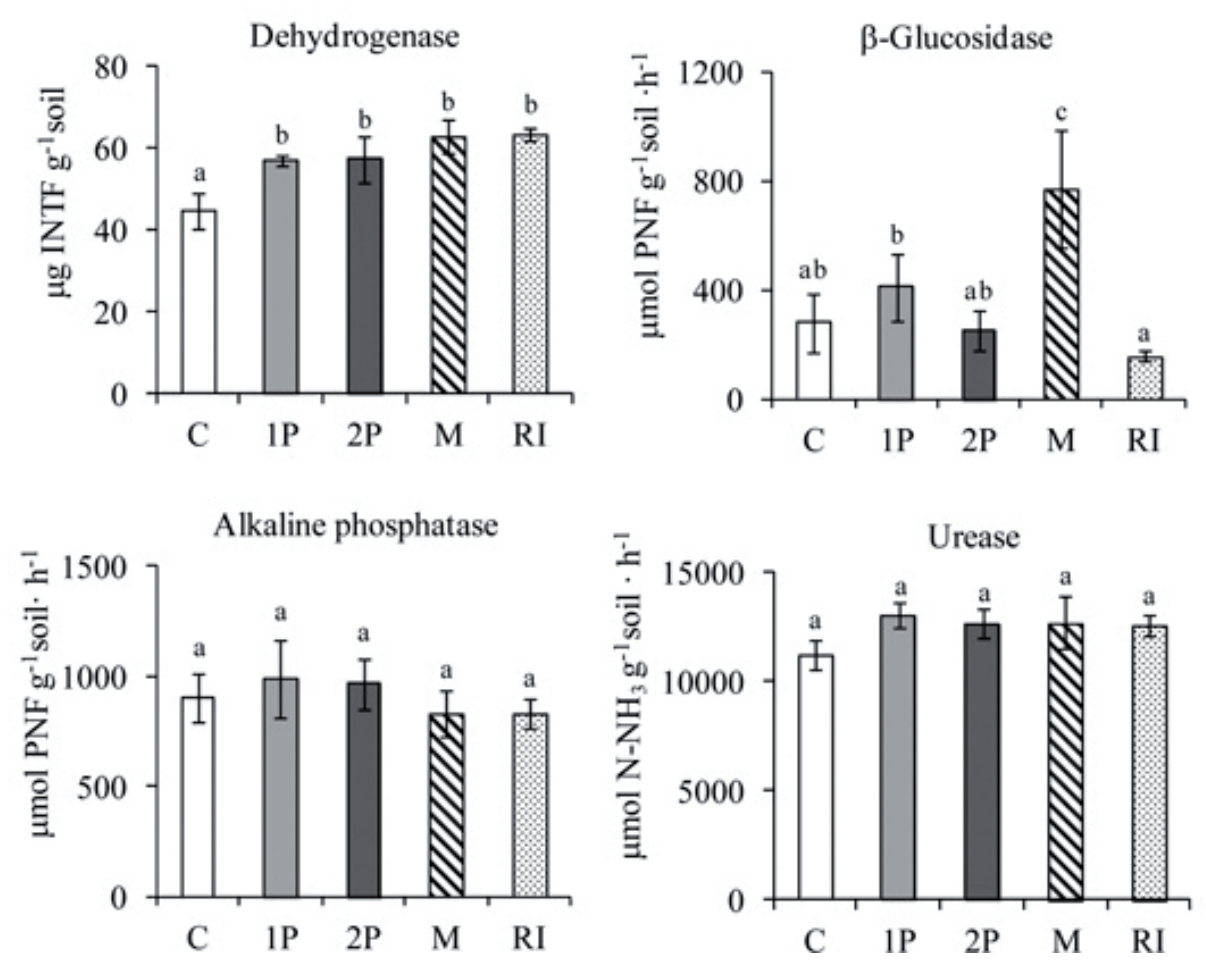

Figure 2. Comparative effect of fertilizers [1P (25 ppm P); 2P (50 ppm P)], authochthonous AM fungal consortium $(\mathrm{M})$ or the reference $R$. intraradices (RI), over control (C) on dehydrogenase, $\beta$-glucosidase, alkaline phosphatase and urease enzymatic activities in soil under drought conditions. Within each value bars having a common letter are not significantly different $(p \leq 0.05)$ as determined by Duncan's multiple-range test $(n=3)$.

\subsection{Experiment II}

Growth of untreated control plants was not represented since it resulted negligible in this experiment which is indication on the effectiveness of applied treatments. The shoot biomass of $R$. sphaerocarpa plants was the highest in $1 \mathrm{~K}$ fertilized plants irrespective of inocula applied (Table 3). The highest $\mathrm{K}$ level $(2 \mathrm{~K})$ has a reducing, but non-significant effect on shoot growth particularly in inoculated plants. The highest level of K-fertilization $(2 \mathrm{~K})$ increased root growth, but the inocula reduced this value (Table 3 ). The comparative effect on plant biomass production shows that inoculation was not important for plant growth promotion irrespective of a lower $(5 \mathrm{mM} \mathrm{K})$ or a higher $(10 \mathrm{mM} \mathrm{K}) \mathrm{K}$ level in the growing medium. Regarding plant nutrition a significant increase of P (583.3\%), K (78.6\%), Zn (90.8\%) and $\mathrm{Cu}(219 \%)$ content was obtained in inoculated plants compared to the respective $1 \mathrm{~K}$ fertilized non-inoculated plants (Table 3) under drought conditions. In contrast, the microbial inocula interaction with $2 \mathrm{~K}$ decreased the plant acquisition of $\mathrm{K}, \mathrm{Ca}, \mathrm{Fe}$ and $\mathrm{Mn}$ compared to single $2 \mathrm{~K}$ fertilized plants. Nevertheless, $2 \mathrm{~K}$ fertilization enhanced $\mathrm{P}, \mathrm{K}$ and $\mathrm{Mn}$ contents compared to the lowest $\mathrm{K}$ level (1K) (Table 3). 
Table 3. Comparative effect of fertilizers $[1 \mathrm{~K}(5 \mathrm{mM} \mathrm{K})$ and $2 \mathrm{~K}(10 \mathrm{mM} \mathrm{K})]$ in interaction or not with autochthonous fungal consortium (M) and B. thuringiensis (B) on the dry weight of shoot and root $(\mathrm{g})$ and content of $\mathrm{P}, \mathrm{K}, \mathrm{Ca}, \mathrm{Mg}$ (mg per plant), $\mathrm{Fe}, \mathrm{Mn}, \mathrm{Zn}$ and $\mathrm{Cu}$ ( $\mu \mathrm{g}$ per plant) of $R$. sphaerocarpa under drought conditions.

\begin{tabular}{lcccccccccc}
\hline & $\begin{array}{c}\text { Shoot } \\
\text { dry } \\
\text { weight }\end{array}$ & $\begin{array}{c}\text { Root } \\
\text { dry } \\
\text { weight }\end{array}$ & $\mathrm{P}$ & $\mathrm{K}$ & $\mathrm{Ca}$ & $\mathrm{Mg}$ & $\mathrm{Fe}$ & $\mathrm{Mn}$ & $\mathrm{Zn}$ & $\mathrm{Cu}$ \\
\hline $1 \mathrm{~K}$ & $2.46 \mathrm{ab}$ & $1.88 \mathrm{a}$ & $0.6 \mathrm{a}$ & $15.4 \mathrm{a}$ & $16.9 \mathrm{~b}$ & $6.0 \mathrm{~b}$ & $121.8 \mathrm{~b}$ & $104.8 \mathrm{a}$ & $46.9 \mathrm{a}$ & $3.7 \mathrm{a}$ \\
$2 \mathrm{~K}$ & $2.14 \mathrm{a}$ & $2.58 \mathrm{~b}$ & $1.8 \mathrm{~b}$ & $24.7 \mathrm{~b}$ & $19.3 \mathrm{~b}$ & $5.5 \mathrm{ab}$ & $127.3 \mathrm{~b}$ & $157.6 \mathrm{~b}$ & $48.4 \mathrm{a}$ & $2.5 \mathrm{a}$ \\
$1 \mathrm{~K}+\mathrm{MB}$ & $2.92 \mathrm{~b}$ & $2.09 \mathrm{ab}$ & $4.1 \mathrm{c}$ & $27.5 \mathrm{~b}$ & $11.1 \mathrm{a}$ & $3.7 \mathrm{a}$ & $104.5 \mathrm{~b}$ & $67.5 \mathrm{a}$ & $89.5 \mathrm{c}$ & $11.8 \mathrm{c}$ \\
$2 \mathrm{~K}+\mathrm{MB}$ & $1.73 \mathrm{a}$ & $1.87 \mathrm{a}$ & $2.0 \mathrm{~b}$ & $13.0 \mathrm{a}$ & $10.1 \mathrm{a}$ & $4.7 \mathrm{ab}$ & $75.2 \mathrm{a}$ & $75.6 \mathrm{a}$ & $68.3 \mathrm{~b}$ & $5.4 \mathrm{~b}$ \\
\hline
\end{tabular}

Within each parameter values having a common letter are not significantly different $(p \leq 0.05)$ as determined by Duncan's multiple-range test $(\mathrm{n}=5)$.

Table 4. Mycorrhizal symbiotic development by the authochthonous AM fungal consortium (M) plus $B$. thuringiensis $(\mathrm{B})$ with whatever of $\mathrm{K}$ fertilizers $[1 \mathrm{~K}(5 \mathrm{mM})$ and $2 \mathrm{~K}(10 \mathrm{mM})]$ on colonization frequency $(\% \mathrm{~F})$, intensity $(\% \mathrm{M})$, intensity of colonization $(\% \mathrm{~m})$, arbuscule abundance $(\% \mathrm{a})$ and richness of arbuscules $(\% \mathrm{~A})$.

\begin{tabular}{lccccc}
\hline & $\% \mathrm{~F}$ & $\% \mathrm{M}$ & $\% \mathrm{~m}$ & $\% \mathrm{a}$ & $\% \mathrm{~A}$ \\
\hline $1 \mathrm{~K}+\mathrm{MB}$ & $74.7 \mathrm{a}$ & $8.4 \mathrm{~b}$ & $10.5 \mathrm{~b}$ & $46.2 \mathrm{~b}$ & $4.7 \mathrm{~b}$ \\
$2 \mathrm{~K}+\mathrm{MB}$ & $83.3 \mathrm{a}$ & $1.4 \mathrm{a}$ & $1.6 \mathrm{a}$ & $34.8 \mathrm{a}$ & $0.5 \mathrm{a}$
\end{tabular}

Within each parameter values having a common letter are not significantly different $(p \leq 0.05)$ as determined by Duncan's multiple-range test $(\mathrm{n}=5)$

The impact of each K level on the development of the mycorrhizal colonization was only relevant regarding values as intensity $(\% \mathrm{M}$ and $\% \mathrm{~m})$ and richness of arbuscules (\%a and \%A). Both mycorrhizal parameters were highly depressed by $2 \mathrm{~K}$ fertilization (Table 4 ). All antioxidant activities determined were enhanced by the highest $\mathrm{K}(2 \mathrm{~K})$ level applied (Figure 3 ). The strongest depressing effect in the antioxidant activi- ties was observed as result of K-fertilization and inocula interaction. The lowest values of whatever antioxidant activity was measured in inoculated plants irrespective of $\mathrm{K}$ level being CAT and GR totally depressed. The SOD and APX activities also decreased by the microbial inoculation applied being SOD 1.8 $(1 \mathrm{~K})$ and $2.4(2 \mathrm{~K})$ times lower while APX was reduced by $2.33(1 \mathrm{~K})$ and $5.92(2 \mathrm{~K})$ times (Figure 3). 
The treatments applied did not change dehydrogenase and urease enzymatic activities. Regarding $\beta$-glucosidase, this activity increased with the higher level of $\mathrm{K}$ and also as result of microbial inoculation. In fact, inoculated plants with $2 \mathrm{~K}$ resulted most effective in increasing $\beta$-glucosidase activity in rhizosphere soil (Figure 4). Nevertheless, the inocula behaved in a different way regarding the alkaline phos- phatase activity since the inocula highly enhanced this activity associated to $1 \mathrm{~K}$. Non-significant differences between $1 \mathrm{~K}$ and $2 \mathrm{~K}$ and between $2 \mathrm{~K}$ with and without inocula were found (Figure 4).

As in the Experiment I, no nodules were formed by native rhizobial population in roots of $R$. sphaerocarpa plants despite an extract of natural soil being added, after transplanting, in all the pots.
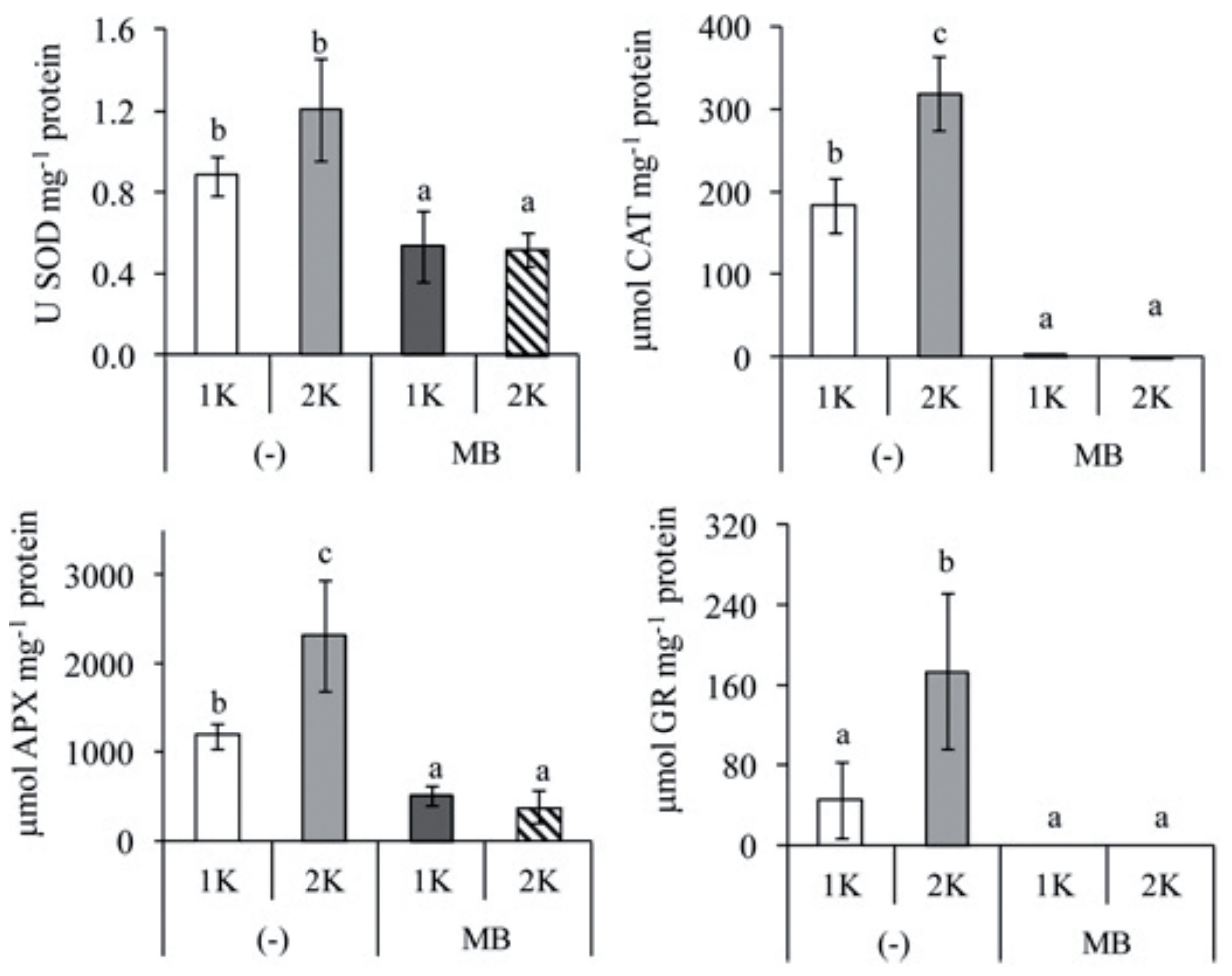

Figure 3. Comparative effect of fertilizers $[1 \mathrm{~K}(5 \mathrm{mM} \mathrm{K})$ and $2 \mathrm{~K}(10 \mathrm{mM} \mathrm{K})]$ in interaction or not with authochthonous mycorrhizal fungal consortium (M) and B. thuringiensis (B) on superoxide dismutase (SOD), catalase (CAT), ascorbate peroxidase (APX) and glutathione reductase (GR) antioxidant activities in shoot of $R$. sphaerocarpa under drought conditions. Within each value bars having a common letter are not significantly different $(p \leq 0.05)$ as determined by Duncan's multiple-range test $(\mathrm{n}=3)$. 
Dehydrogenase
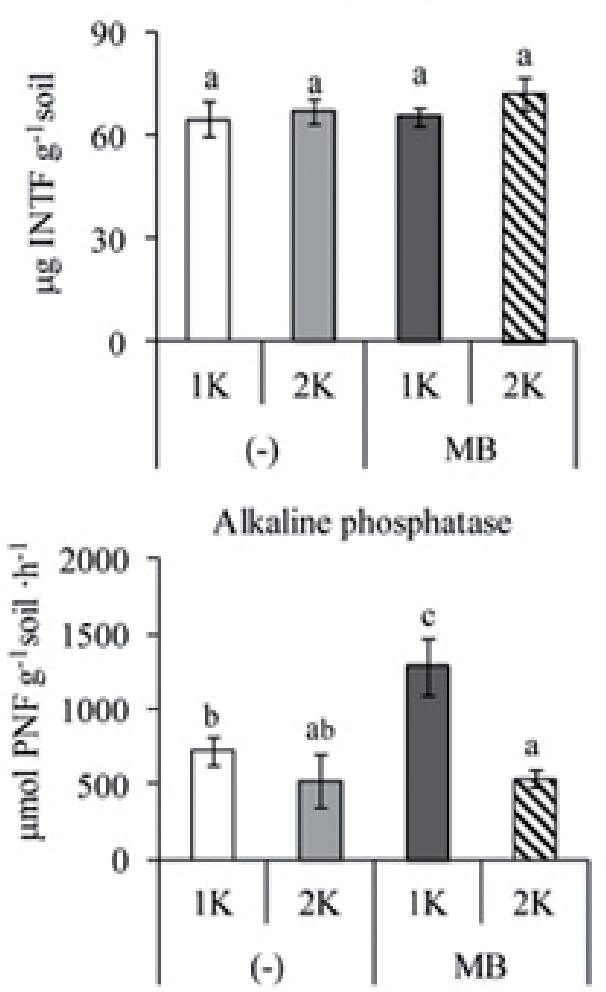
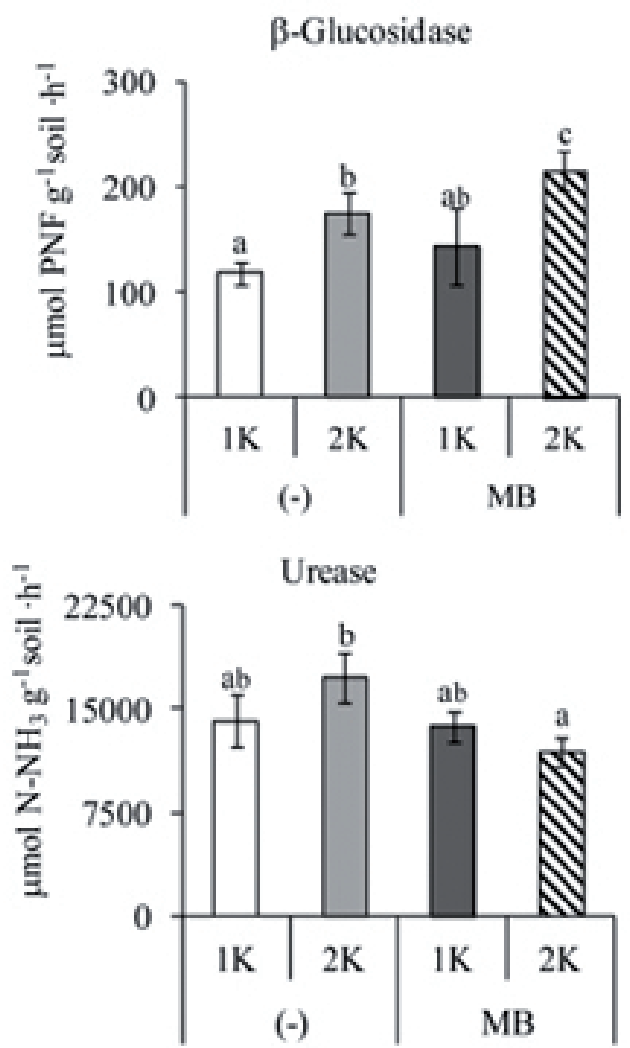

Figure 4. Comparative effect of fertilizers $[1 \mathrm{~K}(5 \mathrm{mM} \mathrm{K})$ and $2 \mathrm{~K}(10 \mathrm{mM} \mathrm{K})]$ in interaction or not with authochthonous mycorrhizal fungal consortium (M) and B. thuringiensis (B) on dehydrogenase, $\beta$-glucosidase, alkaline phosphatase and urease enzymatic activities in soil under drought conditions. Within each value bars having a common letter are not significantly different $(p \leq 0.05)$ as determined by Duncan's multiple-range test $(n=3)$.

\section{Discussion}

Here we addressed the comparative role of $\mathrm{P}$ fertilization rate (25 or $50 \mathrm{ppm}$ ) and of mycorrhizal symbiosis (from allochthonous and autochthonous strains) in the drought tolerance of $R$. sphaerocarpa plants growing in an arid Mediterranean soil.
The comparative effect of single $R$. intraradices from collection vs. the whole autochthonous AM fungal community evidenced non-significant differences in terms of mycorrhizal colonization, growth and nutritional content ( $\mathrm{K}, \mathrm{Ca}$ and $\mathrm{Mg}$ ). Moreover, the fungus $R$. intraradices resulted to be more efficient on $\mathrm{P}$ acquisition and less on $\mathrm{Fe}, \mathrm{Mn}, \mathrm{Zn}$ and $\mathrm{Cu}$. Our initial hypothesis was that the autochthonous fungal 
community ought to be the most efficient inocula under these experimental conditions as suggested by Caravaca et al. (2005) in promoting P uptake, more than the autochthonous AM consortium or whatever level of P fertilizer applied ( 25 or $50 \mathrm{ppm}$ ). Marulanda et al., (2003) reported that the different impact of mycorrhizal inocula to improve plant growth under drought stress may be attributed to the differences in intra and/or extraradical colonization and proportion of active structures as arbuscules, but in this study the mycorrhizal inoculated plants did not vary in their mycorrhizal development.

Results show that the mycorrhizal inoculation irrespective of fungal origin resulted as positive as phosphorus fertilization in improving $R$. sphaerocarpa growth. In fact, both mycorrhizal inocula behaved differently regarding $R$. sphaerocarpa nutrient acquisition in spite of similar frequency/intensity and arbuscular development of these mycorrhizal colonizations. No correlation between mycorrhizal root colonization and $\mathrm{P}$ nutrition was found since no differences in terms of intraradical mycorrhizal development were observed between the two mycorrhizal inocula used.

In general, AM symbiosis can increase plant biomass due to the highest acquisition of nutrients specially those having low mobility. The content of $\mathrm{P}$ was maximized in $R$. sphaerocarpa plants colonized by the reference $R$. intraradices and this nutritional effect could be associated with a greater ability for $\mathrm{P}$ transfer from soil to the plant for the colonizing RI fungus. The allochthonous RI maintained its positive effect under water stress when inoculated in soil different from their isolation source.

The nutritional results were not related to the growth effect when comparing chemical (1P or 2P) and biological ( $\mathrm{M}$ or $\mathrm{RI}$ ) fertilization. The increased $\mathrm{K}$ and $\mathrm{P}$ content in inoculated plants could have enhanced some physiological and biochemical plant parameters, which may be even more relevant than the nutrition in the tolerance under drought associated with the mycorrhizal activity. It is well known that $\mathrm{K}$ has an important role as inorganic osmolyte, which in turn increases the osmotic potential within the cell, while $\mathrm{Ca}$ is important in membrane protection and $\mathrm{Mg}$ modulates ionic currents across the chloroplasts and vacuole membranes (regulating stomatal opening and ion balance in cells) under dry conditions (Parida and Jha 2013). The enhancement of Mg content in mycorrhizal plants suggests that the functioning of photosynthetic apparatus was not affected by drought in mycorrhizal colonized $R$. sphaerocarpa, though drought lends to severe damage to membrane integrity in many plants (Silva et al. 2010).

Antioxidant processes reflect the modified redox status of the stressed cells in plants (Gururani et al. 2013). Thus, specific antioxidant activities, particularly APX, were highest in P fertilized plants and lowest in mycorrhizal plants. These results suggest that water seems to be less limited in mycorrhizal plants and thus, these plants did not require to increase APX and CAT activities to counteract ROS production by drought stress (Armada et al. 2014). Results indicate that P-fertilized plants suffer a stronger drought stress than mycorrhizal plants having similar growth and nutrition. Antioxidant activities have been proposed as stress indexes since they are highly sensitive to the metabolic and physiological status of plants (Ortiz et al. 2015). The efficient destruction of $\mathrm{O}^{2-}$ and $\mathrm{H}_{2} \mathrm{O}_{2}$ generated under water stress requires the action of antioxidant enzymes acting in synchrony to minimize these toxic radicals. Lowest activities of antioxidant enzymes were found in mycorrhizal plants, which preclude a direct role of these enzymes in this process. Particularly APX activity is the main antioxidant related with the maintenance of osmotic balance and also it may facilitate the nutrient uptake in colonized plants. Different roles of this symbiosis in drought 
alleviation in relation to changes in particular antioxidant activities have been reported ranging from increase (Garg and Kaur 2013) to decrease (Yang et al. 2009). Alternatively, different changes on such activities in plants colonized by different fungi have been found (Marulanda et al. 2007). The lowest APX activity in mycorrhizal plants than in P-fertilized plants of similar development supports the view of the crucial role of this symbiosis in alleviating drought stress. The lowest CAT and SOD activities (in AMcolonized plants) and GR activity (in $R$. intraradices inoculated plants) also indicates drought-tolerance in mycorrhizal plants. These results may be regarded as greater protective capacity and as a proof of maintenance of water uptake under low water availability. The autochthonous fungi (M) and also RI resulted an essential component to protect plants against stress conditions. However, the combinations of nutritional, physiological and biochemical mechanisms seem to play a crucial role in drought tolerance. These results suggest that to successfully establish plant in drought arid areas it is important to use efficient and adapted mycorrhizal fungi.

The comparisons of autochthonous mycorrhizal (M) and P-fertilized plants having similar P nutrition and root dry weight, but different antioxidant activities and elements such as $\mathrm{Fe}, \mathrm{Mn}, \mathrm{Zn}$ and $\mathrm{Cu}$ have relevance and important impact in plant physiological and biochemical processes related to the drought tolerance (Ruíz-Lozano and Azcón 1995). These results allow to conclude that independent and additional mechanisms other than nutritional are involved in the drought tolerance of mycorrhizal plants (Augé 2004). Nevertheless, the differences in these parameters between both mycorrhizal inocula preclude any broader generalization.

From experiment II we showed that the combination of autochthonous microorganisms applied (AM fungi consortium plus $B$. thuringiensis) resulted highly effective in improving $\mathrm{P}, \mathrm{K}, \mathrm{Zn}$ and $\mathrm{Cu}$ content only at the lowest $\mathrm{K}$ level applied ( $5 \mathrm{mM} \mathrm{K})$, but not at the highest $\mathrm{K}$ level $(10 \mathrm{mM})$ in the growing medium. According to these results the potential of inocula to alleviate drought stress was limited beyond a certain level of $\mathrm{K}$.

The $2 \mathrm{~K}$ level (10 $\mathrm{mM} \mathrm{K}$ ) increased $\mathrm{P}, \mathrm{K}$ and $\mathrm{Mn}$ over $1 \mathrm{~K}(5 \mathrm{mM} \mathrm{K})$ in $R$. sphaerocarpa shoots, but at this highest level of $\mathrm{K}$ the AM colonization was highly depressed (particularly intensity and arbuscule abundance).

The inocula did not affect $R$. sphaerocarpa growth, but in contrast, pronounced differences in nutrient assimilation was shown according to the inocula/K level interaction. Here, the highest $\mathrm{P}$ and $\mathrm{K}$ plant content in $1 \mathrm{~K}$ inoculated plants correlated with the highest intraradical mycorrhizal colonization determined. High differences in these values were observed among plants inoculated under each one of these two K levels. Differences in the amount of active fungal structures as arbuscules is an explanation for the better fungal performance and functioning in arid environments as have suggested by Marulanda et al., (2003).

In the experiment I, whatever chemical or biological treatment applied increased dehydrogenase activity particularly each one of the mycorrhizal inocula. This enzymatic activity reflected soil microbial community. The reactivation of the rhizosphere microbial populations by the inocula is an indication of rehabilitation of degraded soils. $\beta$-glucosidase activity was only increased in soil inoculated with the autochthonous mycorrhizal consortium (M) that was increased by 2.76 times, which indicates carbohydrates transformation that is important as energy source for microorganism. Consequently, mycorrhizal inoculation not only increased plant characteristics, but also the microbial properties and quality of arid soils. In a previous study (Azcón et al. 2013) reported that autochthonous mycorrhizal fungi not only affected the bacterial 
microbial structure, but also increased the microbial diversity (by 233\%) compared to P fertilization.

Similarly, in Experiment II, the inocula significantly increased the phosphatase activity (in $1 \mathrm{~K}$ fertilized soil) and $\beta$-glucosidase activity (in $2 \mathrm{~K}$ fertilized soil). Measurement of these soil hydrolases are indicators of changes in soil fertility since they are involved in the mineralization of compounds that provide nutrients as N, P and C. The effectiveness of inocula in this experiment was based on a direct improvement of nutrient status particularly $\mathrm{P}, \mathrm{K}, \mathrm{Zn}$ and $\mathrm{Cu}$. The highest $\mathrm{P}$ shoot content in these plants could be explained by the PGPR (plant growth promoting rhizobacteria) abilities of inocula applied and also by the highest value of phosphatase activity in the rhizosphere of these plants. The main role of this phosphatase is to catalyze the hydrolysis of organic phosphates increasing the $\mathrm{P}$ available to plants and thus improving plant $P$ uptake. The enhancement of soil enzyme activities, particularly $\beta$-glucosidase, by the inocula may be related to the reactivation of the rhizosphere microbial population by increasing water soluble C. Carbohydrates are also involved in aggregate stabilization and soil water retention. Thus, these values indicated that the applied inocula may enhance rehabilitation of arid degraded soils contributing to soil fertility and quality (Medina and Azcón 2012).

As the results show, the higher performance of inoculated plants than those fertilized reaffirm the important role of inocula applied in sustaining the plant cover under drought in these nutrient deficient arid soils.

\section{Conclusions}

The mycorrhizal effect in enhancing shoot biomass and growth was similar to this produced by P fertilization however a drop in particular antioxidant activities in mycorrhizal colonized plants as APX (by M and RI inocula) CAT (by M inoculum) and GR (by RI inoculum) may indicate the highest potential of mycorrhizal colonization to alleviate drought stress in these plants.

Inocula $(\mathrm{M}+\mathrm{B})$ positively interacted on nutrient acquisition with the lowest $\mathrm{K}$ fertilization $(5 \mathrm{mM} \mathrm{K}$ ) and negatively with the highest (10 $\mathrm{mM} \mathrm{K})$. Lower SOD and APX activities and the suppression of CAT and GR in inoculated K-fertilized plants may indicate the highest ability of inoculated plants to cope with drought independently of nutritional status.

Mycorrhizal inoculants may be more important than chemical fertilization orchestrating antioxidant activities along the process of drought tolerance.

\section{Acknowledgments}

E. Armada was financed by Ministry of Science and Innovation (Spain). This work was carried out in the framework of the project reference AGL200912530-C02-02. We thank the Instrumentation Service (EEZ-CSIC) for the plant analysis. We thank Shaun Smith (native English teacher) for their assistance in the revision of this article.

\section{References}

Aebi, H. 1984. Catalase in vitro. Methods Enzymol. 105, 121-126.

Amako, K., Chen, G.X., Asada, K. 1994. Separate assays specific for ascorbate peroxidase and guaiacol peroxidase and for the chloroplastic and cytosolic isozymes of ascorbate peroxidase in plants. Plant Cell Physiol. 35, 497-504.

Armada, E., Roldán, A., Azcón, R. 2014. Differential activity of autochthonous bacteria in controlling drought stress in native Lavandula and Salvia plants species under drought conditions in natural arid soil. Microb. Ecol. 67, 410-420. 
Armada, E., Azcón, R., López-Castillo, O.M., CalvoPolanco, M., Ruiz-Lozano, J.M. 2015. Autochthonous arbuscular mycorrhizal fungi and Bacillus thuringiensis from a degraded Mediterranean area can be used to improve physiological traits and performance of a plant of agronomic interest under drought conditions. Plant Physiol. Biochem. 90, 64-74.

Aroca, R., Irigoyen, J.J., Sánchez-Díaz, M. 2003. Drought enhances maize chilling tolerance. II. Photosynthetic traits and protective mechanisms against oxidative stress. Physiol. Plant. 117, 540549.

Augé, R.M. 2004. Arbuscular mycorrhizae and soil/ plant water relations. Can. J. Soil Sci. 84, 373381.

Azcón, R., Medina, A., Aroca, R., Ruíz-Lozano, J.M. 2013. Abiotic stress remediation by the arbuscular mycorrhizal symbiosis and rhizosphere bacteria/ yeast interactions. In: F.J. de Bruijn (ed). Molecular Microbial Ecology of the Rhizosphere. John Wiley \& Sons, Hoboken, New Jersey, USA, pp: 991-1002.

Bradford, M.M. 1976. Rapid and sensitive method for quantitation of microgram quantities of protein utilizing principle of protein-dye binding. Anal. Biochem. 72, 248-254.

Burd, G.I., Dixon, D.G., Glick, B.R. 2000. Plant growth promoting bacteria that decreased heavy metal toxicity in plants. Can. J. Microbiol. 46, 237-245.

Caravaca, F., Alguacil, M.M., Barea, J.M., Roldán, A. 2005. Survival of inocula and native AM fungi species associated with shrubs in a degraded Mediterranean ecosystem. Soil Biol. Biochem. 37, 227-233.

Carlberg, I., Mannervik, B. 1985. Glutathione reductase. Methods Enzymol. 113, 484-489.
Duncan, D.B. 1955. Multiple range and multiple F tests. Biometrics. 11, 1-42.

García, C., Hernández, M.T., Costa, F. 1997. Potential use of dehydrogenase activity as an index of microbial activity in degraded soils. Commun. Soil Sci. Plant Nutr. 28, 123-134.

Garg, N., Kaur, H. 2013. Response of antioxidant enzymes, phytochelatins and glutathione production towards $\mathrm{Cd}$ and $\mathrm{Zn}$ stresses in Cajanus cajan (L.) Millsp genotypes colonized by arbuscular mycorrhizal fungi. J. Agron. Crop Sci. 199, 118-133.

Giovannetti, M., Mosse, B. 1980. Evaluation of techniques for measuring vesicular arbuscular mycorrhizal infection in roots. New Phytol. 84, 489-500.

Gururani, M.A., Upadhyaya, C.P., Baskar, V., Venkatesh, J., Nookaraju, A., Park, S.W. 2013. Plant growth-promoting rhizobacteria enhance abiotic stress tolerance in Solanum tuberosum through inducing changes in the expression of ROS-scavenging enzymes and improved photosynthetic performance. J. Plant Growth Regul. 32, 245-258.

Jeffries, P., Barea, J.M. 2012. Arbuscular Mycorrhiza - a key component of sustainable plant-soil ecosystems. In: B. Hock (ed). The Mycota, a comprehensive treatise on fungi as experimental systems for basic and applied research. Springer, Berlin, Heidelberg, pp: 51-75.

Koussevitzky, S., Suzuki, N., Huntington, S., Armijo, L., Sha, W., Cortes, D., Shulaev, V., Mittler, R. 2008. Ascorbate peroxidase 1 plays a key role in the response of Arabidopsis thaliana to stress combination. J. Biol. Chem. 283, 34197-34203.

Loutfy, N., El-Tayeb, M.A., Hassanen, A.M., Moustafa, M.F.M., Sakuma, Y., Inouhe, M. 2012. Changes in the water status and osmotic solute contents in response to drought and salicylic acid treatments in four different cultivars of wheat (Triticum aestivum). J. Plant Res. 125, 173-184. 
Marulanda, A., Azcón, R., Ruíz-Lozano, J.M. 2003. Contribution of six arbuscular mycorrhizal fungal isolates to water uptake by Lactuca sativa plants under drought stress. Physiol. Plant. 119, 526533.

Marulanda, A., Barea, J.M., Azcón, R. 2006. An indigenous drought-tolerant strain of Glomus intraradices associated with a native bacterium improves water transport and root development in Retama sphaerocarpa. Microb. Ecol. 52, 670678.

Marulanda, A., Porcel, R., Barea, J.M., Azcón, R. 2007. Drought tolerance and antioxidant activities in lavender plants colonized by native droughttolerant or drought-sensitive Glomus species. Microb. Ecol. 54, 543-552.

Masciandaro, G., Ceccanti, B., García, C. 1994. Anaerobic digestion of straw and piggery wastewater: II. Optimization of the process. Agrochimica. 3, 195-203.

Medina, A., Azcón, R. 2012. Reclamation strategies of semiarid mediterranean soil: improvement of the efficiency of arbuscular mycorrhizal fungi by inoculation of plant growth promoting microorganisms and organic amendments. In: M. Hafidi, R. Duponnois (eds). The Mycorrhizal Symbiosis in Mediterranean Environment: Importance in Ecosystem Stability and in Soil Rehabilitation Strategies. Nova Science Publishers New York, pp: 87-106.

Nannipieri, P., Ceccanti, B., Cervelli, S., Matarese, E. 1980. Extraction of phosphatase, urease, proteases, organic-carbon, and nitrogen from soil. Soil Sci. Soc. Am. J. 44, 1011-1016.

Naseby, D.C., Lynch, J.M. 1997. Rhizosphere soil enzymes as indicators of perturbations caused by enzyme substrate addition and inoculation of a genetically modified strain of Pseudomonas fluorescens on wheat seed. Soil Biol. Biochem. 29, 1353-1362.
Ortiz, N., Armada, E., Duque, E., Roldán, A., Azcón, R. 2015. Contribution of arbuscular mycorrhizal fungi and/or bacteria to enhancing plant drought tolerance under natural soil conditions: Effectiveness of autochthonous or allochthonous strains. J. Plant Physiol. 174, 87-96.

Panozzo, J.F., Eagles, H.A. 1999. Rate and duration of grain filling and grain nitrogen accumulation of wheat cultivars grown in different environments. Aust. J. Agric. Res. 50, 1007-1015.

Parida, A.K., Jha, B. 2013. Physiological and biochemical responses reveal the drought tolerance efficacy of the halophyte Salicornia brachiata. J. Plant Growth Regul. 32, 342-352.

Phillips, J.M., Hayman, D.S. 1970. Improved procedure of clearing roots and staining parasitic and vesicular-arbuscular mycorrhizal fungi for rapid assessment of infection. Trans. Br. Mycol. Soc. $55,159-161$.

Rengel, Z., Marschner, P. 2005. Nutrient availability and management in the rhizosphere: exploiting genotypic differences. New Phytol. 168, 305-312.

Romheld, V., Kirkby, E.A. 2010. Research on potassium in agriculture: needs and prospects. Plant Soil. 335, 155-180.

Ruíz-Lozano, J.M., Azcón, R. 1995. Hyphal contribution to water uptake in mycorrhizal plants as affected by the fungal species and water status. Physiol. Plant. 95, 472-478.

Silva, E.N., Ferreira-Silva, S.L., Fontenele, A.d.V., Ribeiro, R.V., Viégas, R.A., Silveira, J.A.G. 2010. Photosynthetic changes and protective mechanisms against oxidative damage subjected to isolated and combined drought and heat stresses in Jatropha curcas plants. J. Plant Physiol. 167, 1157-1164.

Skujins, J. 1976. Extracellular enzymes in soil. CRC critical reviews in microbiology. 4, 383-421. 
Smith, S.E., Read, D.J., 2008. Mycorrhizal Symbiosis. 3rd edn. Elsevier, Academic Press, New York.

Soil Survey Staff. 2006. "Keys to Soil Taxonomy" 10th ed. USDA. Natural Resources, Conservation Service, Washington DC.

Tabatabai, M.A. 1982. Soil enzymes. In: A.L. Page, E.M. Miller, D.R. Keeney (eds). Methods of Soil Analysis. Part 2, 2nd ed. Agron Monogr 9. ASA and SSSA, Madison, Wisconsi, pp: 501-538.

Tabatabai, M.A., Bremner, J.M. 1969. Use of p-nitrophenyl phosphate for assay of soil phosphatase activity. Soil Biol. Biochem. 1, 301-307.
Trouvelot, A., Fardeau, J.C., Plenchette, C., Gianinazzi, S., Gianinazzi-Pearson, V. 1986. Nutritional balance and symbiotic expression in mycorrhizal wheat. Physiologie Vegetale. 24, 300-300.

White, I., Knight, J.H., Zegelin, S.J., Topp, G.C. 1994. Comments to "considerations on the use of time-domain reflectometry (TDR) for masuring soil water content' by WR Whalley. J. Soil Sci. 45, 503-508.

Yang, J., Kloepper, J.W., Ryu, C.-M. 2009. Rhizosphere bacteria help plants tolerate abiotic stress. Trends Plant Sci. 14, 1-4. 